\title{
Editorial Review of Volume 17
}

This volume of $C S S H$, the first not edited by Sylvia Thrupp, demonstrates that the continuity of topics, like the quality of the articles themselves, rests primarily with the contributors. As a group, the authors in this volume represent all the social sciences except psychology, and they study societies on every continent. There is more than usual on Latin America, too little (as usual) on North America. Most of the articles are explicitly part of that continuing debate that $\mathrm{CSSH}$ was meant to stimulate; and the concerns that underlie them indicate something, on the whole encouraging, about the directions of current research on society and history.

The relationship of economic to political power, now studied without embarrassment as to which perceptions are Marxian, remains a fruitful subject for concrete research. In this sense at least we have gone beyond ideology, and Katzman's analysis of Brazilian frontiers shaped by market forces (17:3) like the emphasis given in this number to patterns of landholding by Wasserstrom and Waterbury are good examples. Similarly, the concept of social class continues to prove a useful analytic tool, particularly perhaps when applied with care to modernizing peasant societies as done in the current number or in David Lane's study of Soviet Kazakh$\operatorname{stan}(17: 2)$.

The social sciences seem also to have moved beyond early theories of modernization, or rather beyond their teleology. Shiner's reminder of the uses as well as the limits of tradition/modernity as an ideal type (17:2) was followed by Ben Dor's discussion (17:3) of ways to employ Huntington's ideas about institutionalization. This renewed interest in political (and social) institutions is one of the benefits of more discriminating approaches to the study of modernization. Ben Dor, in looking for ways to make Huntington's ideas operational, carries the theory one step farther. As he insists, careful distinction between the structural and the behavioral aspects of institutionalization will need to be made; yet their very interrelationship is part of the subject's merit. For institutions exist at the 
intersection of cultural values and social needs, of durable functions and intangible attitudes; their study is thus an attractive point of convergence for various disciplines. Markoff's suggestion (in 17:4) that the expansion of bureaucracy is more than an expansion of central power is thus especially timely. Among social institutions, educational ones in particular are receiving growing attention. There the connection between traditional culture and social mobility can be rather clearly measured; in CSSH the effort to do so produced some striking parallels in the studies by Connor, of contemporary eastern Europe, and by Harrigan, of nineteenth-century France (17:3).

The interaction of values, economic change, and institutions also illumines the essay by Scott and Tilly on women's work (17:1). The subject, as important as it is fashionable, in their hands says something about the very process of social change in which 'traditional' values help shape human adaptation to new opportunities and demands. Once again those buffeted by social change show themselves on closer look to be more than history's victims but also independent actors like the Duala people in Joseph's very different study (17:1) who played upon French and German competition and in doing so developed their own nationalism. In the same number, however, Peter Ekeh argues in more general and controversial terms that Africans' encounter with European rulers had left two distinct standards of public behavior; the colonial past continues to influence the present. That the relationship between values and social change can also be fruitfully studied by beginning with formal thought is demonstrated by Gombrich's analysis of Buddhist Karma and Akhavi's of Islam and socialism in Egypt (17:2).

As patterns of behavior, institutions are not far from social ritual, and that seems now to be an interest that has at last spread beyond the ethnographer. Hallpike's distinction between gifts of things and of services (17:1) might be fruitfully applied to many cultures and is not far from the deferential dialectic that Newby finds in England (17:2). Taken together, the studies of festivals and cartoons that have appeared in earlier volumes of CSSH suggest the possibility (and the utility) of learning to recognize a society's iconography, and Mona Ozouf's treatment of the ceremonials of the French revolution is a delightful example of how sensitivity to symbol and archival research can be combined.

From the careful demography of Plakans, with which this volume began, through the articles on peasants that conclude this number and will continue into the next, the editors of CSSH have sought to maintain standards already set and continue discussions well established, as well as to welcome some new questions. In all of this they have benefited not just from Sylvia Thrupp's example but from her willing assistance, wise advice, and good company. 